\title{
Applying “Theory Of Reasoned Action” To Explain Inter-Firm Cooperation: Empirical Evidence From Vietnamese Enterprises
}

Nguyen Phuc Nguyen, Kobe University, Japan

\begin{abstract}
Inter-firm cooperation has received attention in recent years due to its benefit. However, little has been studied about the role of behavior intention and process by which affects cooperation behavior. From studying influencing factors which come from environmental and organizational sets, the paper will draw clear picture about the determinants of inter-firm cooperation. Based on research survey from Vietnamese enterprises, the results have confirmed the mediator role of cooperation intention which is the heart of theory of reasoned action (TRA) in making inter-firm cooperation. The results also revealed the effect of partner's trust and government direction on this type of relationship. The interesting finding has stemmed from the role of relationship benefit and social influences on inter-firm behavior. The former and the later have impacted on inter-firm behavior in different ways.
\end{abstract}

Keywords: inter-firm relationships; cooperation; trust; regulation; social influences

\section{INTRODUCTION}

C nter-firm relations is that of "mutually oriented interaction between two reciprocally committed partners" ( $\mathrm{Ha}^{\circ}$ kansson \& Snehota, 1995, p.25). This relationship is classified as cooperation, competition and coopetition. Among these, cooperation has become an important strategy because of its benefits. Firstly, cooperation between firms has reduced experimental and transaction costs. Due to large customer base and new technological information within clusters, enterprises can easily recognize market opportunities to make investments in new products or services. As a result of ongoing interaction, a firm share competencies and risks associated with product development among partners (Bengtsson \& Kock, 2000; Dyer \& Chu, 2003). Secondly, cooperation between firms will not only promote knowledge sharing and innovation but also enhance firm competitive ability (Rosenfeld, 1996; Becker \& Dietz, 2004 and Belderbos et al., 2004). Finally, almost studies have certified that cooperation will increase firm's performance as a whole. Axelrod (1984) discovered the benefit of cooperation which leads to high performance for both parties who participate in relationship. It seems to be true that the way to improve firm's performance is to stimulate inter-firm cooperation between companies.

In order to clarify the nature of cooperation and enhance this relationship, researchers have investigated factors influencing this kind of relationship. Findings from empirical studies showed that environment, especially from government, could facilitate partnership between organization (Arku, 2002; Cho \& Yu, 2000 and Inzelt, 2004) or became key obstacles to the development of the non-state business sector (Tran et al, 2009). Furthermore, the characteristics of organization influence cooperation decision between agents (Arku, 2002; Fritsch, 2003; Dowling \& Helm, 2006; Felzensztein \& Gimmon, 2007; Okamuro, 2007 and Saito etal, 2007). Studies mentioned that trust and commitment have been key elements in fostering inter-firm relations (Ring \& Van de Ven, 1992; McMillan \& Woodruff, 1999; Rindlfleisch, 2000; Lancastre \& Lages, 2006 and Edelenbos \& Klijn, 2007). By and large, almost authors have common sense that these above factors affect directly inter-firm relations.

On the other hand, human behavior such as cooperation can be explained by the theory of reasoned action (TRA) introduced by Fishbein \& Ajzen (1975). This theory has been tested (Ryan, M. J. \& Bonfield, 1980; 
Stutzman \& Green, 1982) and was adapted to information system, named as the technology acceptance model (David, 1986). Surprisingly, the key question: "what is the backside mechanism by which trust and other elements constitute cooperative behavior between organizations?" has remained largely unexplored. For example, the person can trust other people but does not decide to make cooperate with him/her (Hwang \& Burgers, 1997). This means that trust and other factors such as commitment, relationship benefit, and partner's reputation cannot fully lead to cooperation decision. Moreover, to the author knowledge, there are few researches which include mediator variable (intention ${ }^{1}$ ) in explaining trust and inter-firm relationship except for Mayer et al (1995), McKnight et al (1998) and Jeffries \& Becker (2008). Although, Jeffries \& Becker (2008) tested TRA, the proposed model was simplified. Therefore, the paper will go some way to overcome limitation of Jeffries \& Becker (2008).

The main objective of the study is to develop and test a model of inter-firm relationship in the assist of TRA by using firm's level data from Vietnamese enterprises. The present study also investigates the reasons for creating the differences from horizontal and vertical cooperation as discussed in Rindlfleisch (2000). The final target of the paper is to examine the real impact of governmental regulation on different sectors in national economy.

The remainder of the paper is organized as follows: Part 2 provides an overview of theoretical background related to the research, and establishes hypotheses discussing factors influencing cooperative decision and the process as well. Part 3 describes empirical model and survey. The main results will be shown and be discussed in part 4. Finally, driving conclusions are all located in part 5.

\section{THEORETICAL BACKGROUND AND HYPOTHESES}

Cooperation has been discussed in the literature in different names such as collaboration (Arku, 2002; Payan, 2007), coordination (Anderson \& Narus, 1990; Morgan \& Hunt, 1994), organization interdependence (Warner, 1995). In this paper, the author used the term "cooperation" representing for all other names and adapt the definition of Aderson \& Narus (1990), defined cooperation as similar or complementary coordinated actions taken by firms in interdependent relationships to achieve mutual outcomes or singular outcomes with expected reciprocation over time. This definition is similar to the definition of Cannon (1999) and Rindfleisch (2000). As mentioned above, although there are many factors contribute to stimulate inter-firm relationships, they can be divided into organizational set, environmental set and the mediator.

2.1. Factors influence the success of cooperation between firms.

2.1.1. Organization set

2.1.1.1. The effects of trust on cooperation

To begin with the organizational set, there are vast definitions of trust from various fields. In social psychology, trust is personal trait or social aspects (Blomqvist, 1997). In marketing, Anderson and Narus (1990) defined trust as the firm's belief that another company will perform actions that will result in positive outcomes for firm, as well as not take unexpected actions that would result in negative outcomes for firm. In economics and management, Mayer et al. (1995) saw trust as the willingness of a party to be vulnerable to the actions of another party based on expectation that the other will perform a particular action important to the trustor. We can easily realize that trust is only the belief of one person in front of others and this is not a behavior. Therefore, the definition of trust from Rosseau et al (1998), based on review of trust in various fields, is used in this paper. Trust is a psychological state comprising the intention to accept vulnerability based upon positive expectations of the intentions or behavior of another.

As discussed above, company will form cooperation with other parties for many reasons. A lot of researches are devoted to examine factors influence this type of relationships. Among these, trust is widely viewed as a highly effective mode of enhancing cooperation in all types of inter-firm relationships (Ring \& Van de Ven, 1992; Morgan \& Hunt, 1994; Rindfleisch, 2000; Lancastre \& Lages, 2006). Furthermore, from empirical analysis SMEs in Vietnam, McMillan \& Woodruff (1999) noticed that trust influenced trade between firms. According to these authors, a firm trusted its customer enough to offer credit when the customer found hardly to locate an

${ }^{1}$ This is core component in theory of reasoned action (Fishbein \& Ajzen, 1975). 
alternative supplier. In addition, almost authors believe that trust and commitment have direct effect on interorganizational cooperation (Morgan \& Hunt, 1994 and Morris \& Carter, 2005) This is not true based on the theory of reasoned action (Fishbein \& Ajzen (1975). All antecedents have to be mediated by behavior intention. Instead, trust plays a role in shaping behavior intention (Heikki et al, 2008). All these arguments show the link between trust and the inter-firm cooperation intention.

Hypothesis 1. There is a positive relation between trust and cooperation intention in which higher levels of trust will intensify the level of cooperation intention.

\subsubsection{The effect of cooperation result's expectation on cooperation}

The second factor affects inter-firm cooperation is the expectation from cooperation result. Organizations will build relationship with other parties when cooperation per se takes on a positive value. According to Morgan \& Hunt (1994) and Friman et al. (2002), firms receive superior benefits from partnership will commit themselves into this type of relations. Moreover, an extra-organizational value which creates the feeling that cooperation is substantially good may stimulate firms in forwarding the direction of inter-firm cooperation (Schermerhorn, 1975). This is also true with Evan (1965) who suggested that value expectancy will pull organizations into cooperation. Besides, from economic point of view, Silipo (2005) confirmed that both theoretical model (dynamic patent race model) and the statistical estimates showed high level of cooperation when players were matched and the prize for cooperation was big enough. As the same fashion, Huybers \& Bennett (2003) showed the effect of demand-sidedriven incentive for cooperation action. The greater the expected value from the demand for joint product sold by group members, the greater the incentives for the chances of cooperative arrangements. This seems that without benefit from cooperation, firm will not engage in this type of relationship.

But whether this expectation will influence inter-organizational cooperation directly or not? All researchers have agreed that this component will affect cooperation indirectly through enhancing commitment level. Moreover, both the theory of reasoned action (Fishbein \& Ajzen, 1975) and technology acceptance model (David, 1986) suggested that relationship benefit will increase behavior intention. All the things lead us to the following hypothesis:

Hypothesis 2. There is the positive relationship between cooperation result expectation (relationship benefit) and cooperation intention.

\subsubsection{Environmental Set}

\subsubsection{The Direction From Government On Inter-Firm Intention}

Apart from trust and relationship benefit, regulation from government has played critical roles to cooperation between firms (Nakamura et al., 1997). In most developed economy, government issued local, regional and national policy with the aim at fostering inter-firm cooperation. Rosenfeld (1996) exhibited the efficiency of public program in Denmark. By making a large investment to the support-called program over finite of time, government hoped that by proving the value of networks, cooperative behavior would become absorbed into the culture. The reasonable object of such programs is to help firms to get the benefit of economy of scale, to compete better in global market (Arku, 2002). In addition, Kipping (1996) from studying the connection between inter-firm relationships and industrial policies, showed that governmental policies have important role for the success of French industry. The nature of inter-firm relations resulted in a significantly different level of government involvement in France and Germany. On the other hand, by restricting competitive pressure from foreign companies, Japanese government through MITI and laws has affected inter-firm cooperation in many aspects such as articulating common goals among Japanese firms, supporting R\&D projects (Nakamura et al., 1997). Alternatively, Adobor (2006) cited that government can facilitate cooperation between companies as the role of third party.

However, since cooperation intention is the psychological part of inter-firm cooperation while cooperation decision is the behavior part of cooperation. Therefore, before reaching cooperation decision, these elements will affect behavior intention directly and indirectly to behavior. Based on these results, we form the following hypothesis: 
Hypothesis 3. There is the positive relationship between direction from government and cooperation intention.

\subsubsection{The Effect Of Social Influences On Inter-Firm Cooperation Intention}

As the usual, company establishes cooperation relations with others due to its expectation on receiving results such as making profit, learning knowledge, experiences or knowhow, taking advantage based on other strength. However, organizations sometimes make the relationship with others just because they are influenced by social norms (Nakamura et al., 1997; Thompson \& Panayiotopoulos 1999; Malhotra \& Galletta, 1999). Without preparing for cooperation in advance, the common project itself creates opportunities as well as pressures for these enterprises. It stimulates parties interact each other. The reasons behind can be stemmed from complementary needs; the role of structural factors in which each company has a position in a network of relationship (Smith et al., 1995). On the contrary, pressure from project can force parties make relations with other parties even they do not want. Perceived social or organizational norms act against cooperation (Jeffries \& Becker, 2008). Therefore, we come up for hypotheses:

Hypothesis 4a. Social influence has positive relationship with inter-firm cooperation intention.

Hypothesis 4b. Social influence has negative relationship with inter-firm cooperation intention.

\subsection{The Mediator For Cooperative Behavior}

According to the theory of reasoned action (TRA), the immediate antecedent of any behavior is the intention to perform the behavior in question ${ }^{2}$. The other factors like trust, commitment are the antecedents of behavior intention. However, there are few researches included this variable in explaining trust as well as behavior in spite of its important role. To the author knowledge, Andaleeb (1995), McKnight et al. (1998) and Jeffries \& Becker (2008) are those writers who integrated this term in their analysis. Cooperative intention is as consistent tendency to engage in cooperation with others to attain goals. This definition is similar to Andalledb (1995) and differs basically from Jeffries \& Becker (2008). Intent to cooperate is not synonymous as goal as the latter. It is broad concept which includes goals. The cooperative intention is the processor which consists of two steps inside. Cooperative intention analyses first-hand knowledge and relevant information and latterly delivers signals towards cooperative behavior as final result. The other role of cooperative intention is the mediator. All of determinants including trust, commitment, social norms, and external events will affect behavior only through cooperative intention. Thus,

Hypothesis 5. Intent to cooperate fully mediates the effects of all determinants on cooperative behavior and has positive relationship with it.

We can see all hypotheses in the following figure.

\footnotetext{
2 Ajzen Icek and Madden Thomas J (1986). Prediction of Goal-Directed Behavior: Attitudes, Intentions, and Perceived Behavioral Control. Journal of Experimental Social Psychology, Vol. 22, p. 454
} 


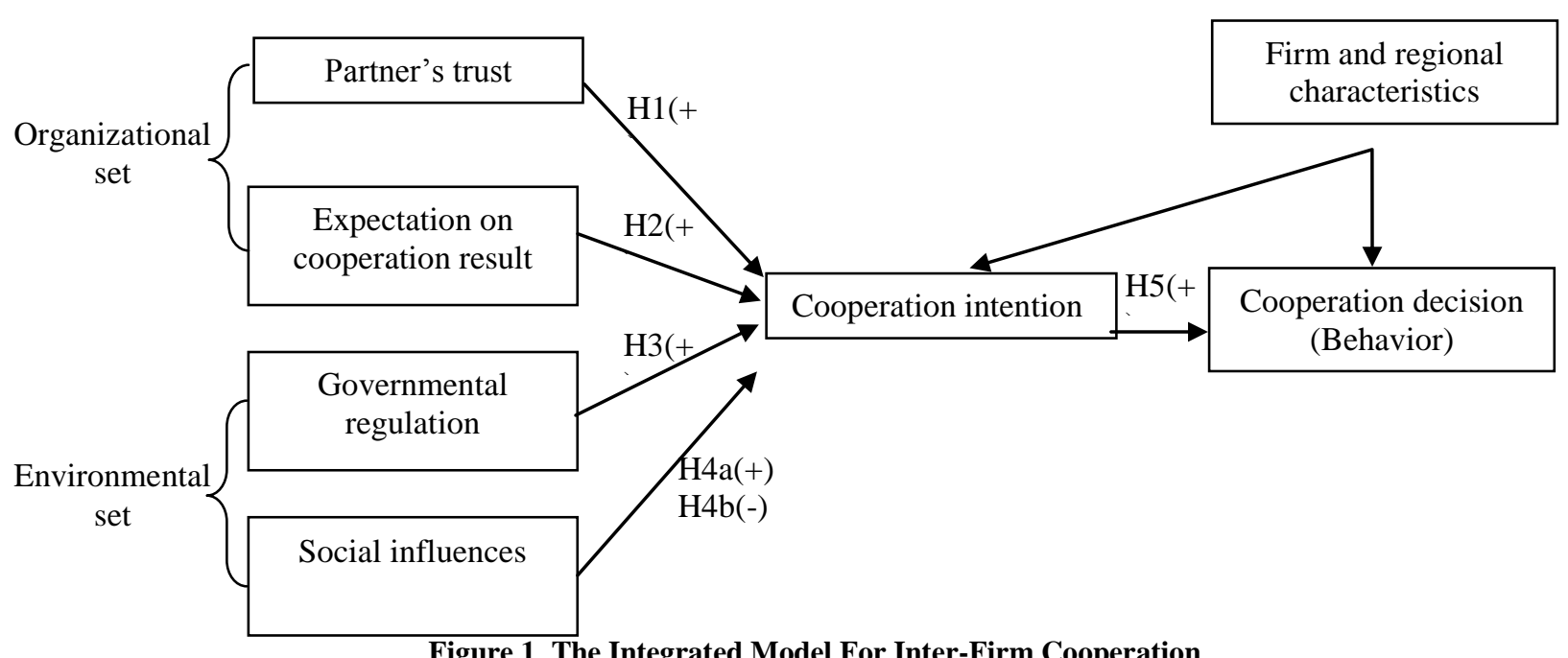

Figure 1. The Integrated Model For Inter-Firm Cooperation

\section{THE SURVEY, VARIABLES AND MODEL}

\subsection{Dataset}

The data used for the analysis was generated through an original survey in three representative urban regions in Vietnam (The north: Hanoi, the Central: Da Nang and the South: Ho Chi Minh City). The survey was carried out from March 2010 to June 2010. In the first stage, the questionnaire was developed and written in English and then translated into Vietnamese. The questionnaire was pretested through in-depth interviews with executives in a sub-sample of four enterprises (one in the north, two in the central and other in the south. Among these subsamples, interviews from different sectors were also implemented as follows: one from public, one from foreign and the remains from private sector). Modifications of the wording and scaling of item were implemented. For the second stage, sample based on population of registered firms was chosen. The study was conducted among 500 companies which consist of 200 in the Central and 150 for each other regions, representing for whole population. Questionnaires, consisted of two versions - printed and soft copy, were sent to target companies including return envelops. Company's managers can also answer the questionnaire by email. After following-up non-respondents through reminder letter and phone-calls, a total of 207 responses were obtained with response rate of $41.4 \%$. However, four of them were not finished or answered by employees, not manager as the requirement. Eliminating these items, the total usable sample is 203.

Because this detailed survey is used for many purposes in author studies, the author only specifies information that is directly used for this paper. From the survey, the majority of participating firms are small size that has less than 200 full-time employees, covers $63.55 \%$ of the survey ${ }^{3}$ (medium size: $19.21 \%$ and large size: $17.24 \%$ ). Almost firms involved in services sector activities-71.92\%, nearly $10 \%$ of enterprises in manufacturing field. This can be the situation of being transition economy of Vietnam. Moreover, about more than half of the formal enterprises originated from private sector and are relatively young. (Appendix A).

\footnotetext{
${ }^{3}$ According to decree No. 56/2009/ND-CP of Vietnamese Government. Small firm has less than 200 full-time employees; Medium firm has full-time employees in range 200-300 and Large firm has more than 300 full-time employees.
} 


\subsection{Variables}

These following variables, along with measurements, are designed to analyze inter-firm behavior for particular relationship or typical project which is on-going or has just finished. In order to test the integrated model mentioned above, different tests below are built on a same structure. Dependent variable in general is dummy variable, which is equal to 1 when a company makes cooperation relationship with particular partners. The same set of independent variables is used to test the effect of additional verification.

\subsubsection{Dependent Variables}

The dependent variable in basic regression is a dummy variable (cooperative behavior: COOP_DECI) which is equal to 1 when firm cooperates with particular partners. The respondent will be asked for behavior in particular project or relations. It thus provides general result on the determinants of inter-firm cooperation which addresses these above hypotheses. From the survey, the ratio of firms which has cooperation with other firms in particular relationship is relatively high, about $73.9 \%$. Using the same dummy variable, control variables will be added to check robustness of the result. To test the effect of each component on inter-firm cooperation with particular sector, the dependent variable is a dummy variable which has value of 1 if the company cooperates with particular public partner, for examples, and 0 otherwise. The same structure is applied to dependent variable for other type of partners: private or foreign partner; horizontal cooperation (competitor) or vertical cooperation (supplier).

\subsubsection{Independent Variables}

\subsubsection{The Moderator And Its Requisite Variables}

The main component of inter-firm cooperation based on theory of reasoned action is intention. "Cooperative intention", which has mathematical symbol as "COOP_INT", means that the company's intends to cooperate with other company in order to get some expectations. The respondent (manager who represents for company in making relationship with other companies or the owners) will be asked to answer his/her company's intention in making relationships with other firms based on other considerations (such as the trust level on partner, the benefit from relationship...) from survey using 7-point Likert scale in which the highest level is 7 . This is the core element for explaining any inter-firm behavior and is used to test hypothesis 5 .

As above discussion, the four independent variables are included as the precedents of intention to cooperate. Among the requisite variables of cooperative intention, the trust toward one's partner effect directly on it. To measure the variable "trust level" which denoted by "BT_LEVEL", one item is designed in the survey. This is interorganizational trust between partners, as introduced by Fang et al. (2008). It is actual trust level at the time of making cooperation decision with other partners (Lancastre \& Lages, 2006).

The second requisite variable is "government direction", represented by "REGULATION", tends to have a positive influence on inter-firm cooperation as mentioned before. This variable measures the effect of government policies or regulation on inter-firm relationship. In the questionnaire, the respondent will evaluate the effect of government actions on inter-firm relationships particularly from industry policies or direction laws. This item will measure whether the inter-firm relationship is shaped by government direction and how much of this effect by using 7-point Likert scale.

One important element in making cooperation between firms is the benefit expectation from that kind of relationships. The expectation from inter-firm relationships (COOP_RES) illustrates the benefit that firm can get through making cooperation with partners. From analyzing the coming cooperation, the representing manager or owner will evaluate the prospect of it using the same above scale.

The last component in this section measures the effect of social influences in particular common project among companies (MANDA). This variable is used to check whether inter-firm cooperation decision is made due to the compulsory relationship when company works in the common project with partners. This is dummy variable that 
takes on the value 1 if inter-firm cooperation occurs because of mandatory relationship in project and 0 otherwise. This variable will measure the effect of social norms under particular project.

\subsubsection{The Control Variables}

The above variables of cooperation behavior should be controlled by two variable sets: firm and regional characteristics.

\subsection{Firm's Characteristics}

Company characteristics have been proved to have significant impact on cooperation behavior and that were controlled for the empirical analysis. They conclude establishment size (measured by number of employee), type of sector, age of company and number of inter-firm relations. According to Fritsch and Lukas (2001), firms are engaged in R\&D cooperation, tend to be large. The positive effect of firm's size on inter-organization cooperation in R\&D field can also be found in Fritsch (2003) and Okamuro (2007). Arku (2002) and Felzenstein \& Gimmon (2007), on the contrary, from studying inter-firm relationship in general, found negative effect of size on inter-firm relationship. Based on resources- base perspective, the author thinks that size of firm has negative effect on interfirm relationship. The smaller the company which lacks resources or wishes to learn new knowledge..., the more ambition is in this type of relations.

On the other hand, with regard to the relationship between firm's age and inter-firm cooperation, the author expects that older firms are likely to have a higher number of cooperative arrangements than younger firms. As the same way, he also assumes that the number of relationships with other firms also has effected on inter-firm cooperation. The more relations with other firms, the less likely that company makes cooperation with others. The final control variable in firm's characteristics set is type of company. Tran et al. (2009), for example, showed the correlation between culture and cooperation. They discovered that cooperation is mostly between non-state SMEs and other domestic private enterprises in the same district/town. Relationships outside of the regions and with SOEs ${ }^{4}$ are few, and there is little cooperation with foreign companies. On the contrary, both domestic and foreign-owned enterprises exhibited low rate of inter-firm cooperation in the study of Arku (2002).

\subsection{Regional Characteristics}

The region, where company located, has influenced inter-firm relationship. This will shape the attitude of company's managers toward this relationship. Fritsch \& Lukas (2001) and Fritsch (2003) revealed the significant differences in cooperation among regions with regard to the propensity to maintain a cooperative relationship. Based on Vietnamese context, the south will prefer cooperation than the north due to the western influence as the result of market-based experience compare with the bureaucracy-rooted economy in the north (Tran et al., 2009).

All detail information about variables is described in Appendix B.

\subsection{Model And Estimation Method \\ 3.3.1. Empirical Model} follows:

In order to analyze the impact of behavior intention on inter-firm cooperation, the empirical model is as

$$
\text { COOP_DECI }{ }_{i}=\beta_{0}+\beta \text { COOP_INT }+\delta X_{i}+\varepsilon_{i}
$$

Where COOP_DECI $\mathrm{i}_{\mathrm{i}}$ is cooperative behavior of firm $\mathrm{i} ; \beta_{0}$ is constant; COOP_INT is cooperative intention; $\beta$ is coefficient of cooperative intention; $X_{i}$ is vector controlling for firm and regional characteristics; $\delta$ is vector of

\footnotetext{
${ }^{4}$ SMEs: Small and medium enterprises. SOEs: State owned enterprises
} 
parameters of $\mathrm{X}_{\mathrm{i}}$ and $\varepsilon_{\mathrm{i}}$ is the error term. Consistent with the logic of the theory of reasoned action, the cooperative intention has it determinants is as:

$$
\begin{aligned}
\text { COOP_INT }_{i}= & \alpha+\mu \mathrm{BT}_{-} \mathrm{LEVEL}_{\mathrm{i}}+\varphi \mathrm{COOP}_{-} \mathrm{RES}_{\mathrm{i}} \\
& +\eta \mathrm{REGULATION}_{\mathrm{i}}+\lambda \mathrm{MANDA}_{\mathrm{i}}+\omega \mathrm{X}_{\mathrm{i}}+v_{i}
\end{aligned}
$$

In which BT_LEVEL, COOP_RES, REGULATION and MANDA are explanatory variables as discussed above; $\omega$ is vector of parameter and $v_{i}$ is the error term.

\subsubsection{Estimation Method}

We estimate the determinants of whether or not firm has made inter-firm cooperation with partners. With dummy variable of COOP_DECI, probit regression method can be used to test all hypotheses with the following form:

$$
\begin{aligned}
\text { COOP_DECI }_{\mathrm{i}} & =\psi_{0}+\psi_{1} \text { COOP_INT }+\psi_{2} \mathrm{BT}_{-} \mathrm{LEVEL}_{\mathrm{i}}+\psi_{3} \text { COOP_RES }_{\mathrm{i}} \\
& +\psi_{4} \text { REGULATION }_{\mathrm{i}}+\psi_{5} \mathrm{MANDA}_{\mathrm{i}}+\xi \mathrm{X}_{\mathrm{i}}+\rho_{i}
\end{aligned}
$$

However, this method is not suitable for the suggested integrated model. Firstly, probit regression cannot explain correctly and fully the effect of cooperative intention on cooperative decision because it treats all variables equally (from equation 3). Cooperative intention is not the mediator for other antecedents as logic of theory of reasoned action-TRA (Fishbein \& Ajzen, 1975). Secondly, cooperative intention is endogenous regressor in equation (1). This is contrast with the requirement of the probit maximum likelihood (ML) estimator. Moreover, consistent estimation requires both normality and homoskedasticity of the error $\varepsilon_{\mathrm{i}}$ and $v_{\mathrm{i}}$. Therefore, the structural approach is used to overcome this disadvantage ${ }^{5}$. In this method, equation (1) can be referred to as "structural" and equation (2) as "reduced-form". Although estimation can be simultaneous or sequential (which using OLS regression in the first stage and probit in second stage), the simultaneous approach is preferred and chosen for testing all hypotheses because it satisfies all conditions [(1) Cooperative intention plays the role of mediator; and (2) it influences cooperative behavior directly and simultaneously through its precedents]. The detailed discussion on this method is given in Appendix C.

\section{ANALYSIS AND FINDINGS}

\subsection{Main Results}

4.1.1. Basic Estimation

The estimation method is instrument variable method which called IV probit. In order to test previous hypotheses, the model is estimated using the STATA 11 package. Empirical results which consist of firm's characteristics for the probit and IVprobit with two estimation approaches are given in Table 1. Although probit regression creates bias in estimating coefficients as discussed above, it and IV probit with two-steps are presented in the first three columns in Table 1 in order to support selected IV probit with ML estimation. In the first column, the mediating role of cooperative intention is not supported. This contrasts with hypothesis 5. In addition, two-steps estimation can show the role of cooperative intention in one hand but the standard error also increases about 3.5 times compared with ML method (in column 4) due to a loss of precision on the other hand. The positive effect of trust on inter-firm cooperation is not exist (p-value of 0.408) and seems strange compared with all other researches. Based on these, the IV probit estimation using ML is correct method.

The result of instrument variable estimation is shown in last two columns in Table 1. Testing for the exogeneity (Wald test) of cooperation intention using IVprobit does reject the null hypothesis, suggesting that the

\footnotetext{
${ }^{5}$ Refer to Cameron, A.C and Trivedi, P. K, (2009) in pp. 465-468 for the discussion about endogenous regressor and structuralmodel approach.
} 
endogenous regressor (COOP_INT) should be used. Moreover, there is a large negative and significant correlation, athrho (another version of rho in STATA package) between the error terms of the instrument equation and inter-firm cooperation equation. This confirms the role of unobserved variables affecting both cooperative intention and cooperative decision. In addition, the last column shows the mediating role of cooperative intention on cooperative behavior. This role is seen clearly through analyzing marginal effect. The marginal effect caused by instrument has increased twice than the estimation without instrument from 0.519 to 1.069 . The robust standard error also decreases nearly a half, simultaneously. All of these strongly support hypothesis 5. This result is similar with findings of Jeffries \& Becker (2008) and is consistent with theory of reasoned action (Fishbein \& Ajzen, 1975).

Table 1. Probit And IVprobit Regression On Inter-Firm Cooperation

\begin{tabular}{|c|c|c|c|c|c|}
\hline VARIABLES & $\begin{array}{c}(1) \\
\text { Probit model }\end{array}$ & $\begin{array}{c}(2) \\
\text { IV probit Two- } \\
\text { step estimates }\end{array}$ & $\begin{array}{l}\text { First stage } \\
\text { regression }\end{array}$ & $\begin{array}{c}\text { (3) } \\
\text { IV probit } \\
\text { ML estimates }\end{array}$ & $\begin{array}{c}\text { Instrument } \\
\text { equation } \\
\text { (COOP_INT) }\end{array}$ \\
\hline \multirow[t]{2}{*}{ Constant } & $-8.199 * * *$ & $-10.433 * * *$ & $2.988 * * *$ & $-5.867 * * *$ & $2.988 * * *$ \\
\hline & $(1.732)$ & $(2.446)$ & $(0.649)$ & $(0.950)$ & $(0.729)$ \\
\hline \multirow[t]{2}{*}{ COOP_INT } & $0.519 * * *$ & $1.927 * * *$ & & $1.069 * * *$ & \\
\hline & $(0.183)$ & $(0.336)$ & & $(0.0953)$ & \\
\hline \multirow[t]{2}{*}{ BT_LEVEL } & $0.595 * * *$ & & 0.0469 & & $0.182 * * *$ \\
\hline & $(0.157)$ & & $(0.0566)$ & & $(0.0389)$ \\
\hline \multirow[t]{2}{*}{ COOP_RES } & $0.323 * *$ & & $0.3836 * * *$ & & $0.248 * * *$ \\
\hline & $(0.134)$ & & $(0.0664)$ & & $(0.0686)$ \\
\hline \multirow[t]{2}{*}{ REGULATION } & $0.262 * *$ & & $0.1039 * *$ & & $0.102 * * *$ \\
\hline & $(0.112)$ & & $(0.0468)$ & & $(0.0358)$ \\
\hline \multirow[t]{2}{*}{ MANDA } & -0.496 & & -0.2378 & & $-0.218 * *$ \\
\hline & $(0.321)$ & & $(0.1504)$ & & $(0.101)$ \\
\hline \multirow[t]{2}{*}{ Small } & $1.771 * * *$ & $1.973 * * *$ & -0.305 & $1.017 * * *$ & $-0.355^{*}$ \\
\hline & \begin{tabular}{|l}
$(0.410)$ \\
\end{tabular} & \begin{tabular}{|l}
$(0.591)$ \\
\end{tabular} & $(0.233)$ & $(0.272)$ & $(0.215)$ \\
\hline \multirow[t]{2}{*}{ Medium } & $1.512 * * *$ & $1.313^{*}$ & 0.029 & $0.602 * *$ & 0.0105 \\
\hline & $(0.371)$ & $(0.680)$ & $(0.252)$ & $(0.242)$ & $(0.195)$ \\
\hline \multirow[t]{2}{*}{ Private } & $0.672 *$ & 0.2071 & 0.094 & 0.147 & 0.0944 \\
\hline & $(0.398)$ & $(0.482)$ & $(0.198)$ & $(0.220)$ & $(0.190)$ \\
\hline \multirow[t]{2}{*}{ Foreign } & $0.910^{*}$ & 0.330 & 0.248 & 0.115 & 0.267 \\
\hline & \begin{tabular}{|l}
$(0.500)$ \\
\end{tabular} & $(0.684)$ & $(0.261)$ & $(0.244)$ & $(0.175)$ \\
\hline \multirow[t]{2}{*}{ Age } & \begin{tabular}{|l|}
0.267 \\
\end{tabular} & $0.397 *$ & $-0.162 * *$ & $0.232 *$ & $-0.165^{*}$ \\
\hline & $(0.179)$ & $(0.209)$ & $(0.080)$ & $(0.131)$ & $(0.0961)$ \\
\hline \multirow[t]{2}{*}{ Relation } & $-0.334 *$ & -0.167 & 0.007 & -0.0876 & -0.0124 \\
\hline & $(0.185)$ & $(0.340)$ & $(0.106)$ & $(0.113)$ & $(0.0962)$ \\
\hline Pseudo R-squared & 0.6409 & & & & \\
\hline Adjusted R-squared & & & 0.2886 & & \\
\hline \multirow{2}{*}{ athrho } & & & & $-1.526 * * *$ & \\
\hline & & & & $(0.245)$ & \\
\hline rho & & & & -0.9098 & \\
\hline$\chi^{2}$ (Wald test of exogeneity) & & $34.62 * * *$ & & $38.77 * * *$ & \\
\hline Observations & 203 & 203 & 203 & 203 & 203 \\
\hline
\end{tabular}

Note: Robust standard errors in parentheses except for two-step estimation (standard errors). Statistically significant at $* * *$ $\mathrm{p}<0.01, * * \mathrm{p}<0.05, * \mathrm{p}<0.1$.

The empirical results in the last column in Table 1 have supported the hypotheses 1, 2, 3 and $4 \mathrm{~b}$ with high level of significant (p-value less than 0.01). Trust between organizations, the expectation in inter-firm relationships and direction from government have positive effect on inter-firm cooperation indirectly through cooperative intention. The results, once again, confirms the important role of trust (hypothesis 1) in fostering inter-firm cooperation intention and cooperation latterly (Morgan \& Hunt, 1994 and Lancastre \& Lages, 2006). Moreover, the meaningful finding from empirical analysis comes from the expectation on relationship benefit. Under firm's level data, received benefit from cooperation seems to be the most contribution to inter-firm relationship intention (this supports hypothesis 2). The expectation can explain the reason for making inter-firm relationships at the first time in 
case of lacking trust among companies. In addition, the intent to cooperate as the signal and cooperative decision as the result are affected mostly by relationship benefit. This is beforehand expectation - not an ex post benefit in Lancastre \& Lages, 2006. Besides, the governmental direction works well based on result. This confirms the role of government in shaping industrial relationships (hypothesis 3) not only in developed countries like France, Germany, Japan and Korea (Kipping, 1996; Nakamura et al., 1997; Cho \& Yu, 2000) but also in transition economy like Vietnam. Surprisingly, social influence especially by compulsory relationship for working in common project reduces indirectly the chance for cooperation between firms (hypothesis $4 \mathrm{~b}$ ). This is contrast with empirical results from developed country like Japan (Hagen \& Choe, 1998). Even though there are opportunities came from big work, social influence represented by compulsory relationship has negative effect on inter-firm intent to cooperation. The reason behind can be because of lacking preparation for such kind of relationships or because of acting against cooperation from organizational norms (Jeffries \& Becker, 2008).

\subsubsection{Robustness Checks}

A number of regressions have been carried out to check for the robustness of regression results. The initial IVprobit without control variables called model 1 is shown in the first two columns in Table 2. The control variables based on company and regional characteristics will be added in succession. Size (Small Medium), type of company (Private, Foreign), age and number of relations (Relation) are added and presented from model 2 to model 5 , respectively. The regional characteristic has been added in model 6 which consists of all control variables locates in the last two columns. The detail correlation among variables is displayed in the Appendix D. Although, trust and cooperation expectation are highly correlated as shown in Appendix D, but test for the problem of multicollinearity is not exist. All VIF are less than 2.8 and tolerances are above 0.3 . Based on rule of thumb, this supports the validity and reliability of empirical results. (Kutner et al., 2004).

Across all regressions, the results strongly support all hypotheses except for hypothesis $4 \mathrm{~b}$ in the last regression. These additional variables have little effect on cooperative determinants coefficients. The role of processor as well as mediator of cooperative intention is consistent in all estimations. Once again, the expectation on relationship benefit continues to be the most important element in enhancing inter-firm cooperation. Trust and regulation has positive relationship with inter-firm cooperation. The effect of compulsory relationship seems to be in weak support from empirical result only for the last model. This result can be the correlation between the regional control variable and compulsory relation based on the survey data. In general, all hypotheses are supported from the analyses.

Moreover, from robustness check, we found that small and medium enterprises are more likely than large firms to undertake inter-firm cooperation. These results are significant across estimations and consistent with the widespread assumption in the literature (i.e Malecki \& Veldhoen, 1993; Arku, 2002). The small and medium firms which lack sufficient internal resources and inter-firm cooperation is the right choice for getting resources as well as learning from others and improving their competitiveness. The type of company has an ambiguous effect on interfirm relationships. Based on the estimation result, we do not see any significant level from those. Therefore, we can conclude that type of company does not affect on inter-firm relationship. Although this evidence is contrast with finding of Tran et al. (2009), it is similar with Arku (2002). Consistent with prediction, age of enterprise shows to be a good predictor for inter-firm cooperation. The older the company gets, the higher chance for cooperation will happen. This finding is also supported from this analysis. On the other hand, the numbers of inter-firm relationships seem to have negative effect on this kind of relations. The company has more relation tends to less cooperate with other. Unfortunately, this is no meaning based on statistical result. Finally, the regional culture reflects clearly the attitude towards inter-firm cooperation is found in the South and Central of Vietnam. More market-minded and the experiences from exposure to world market economy has shaped the south people more open and easier to cooperate comparing with the north (Tran et al., 2009). 


\begin{tabular}{|c|c|c|c|c|c|c|c|c|c|c|c|c|}
\hline VARIABLES & Model 1 & $\begin{array}{c}\text { Instru. } \\
\text { equation }\end{array}$ & Model 2 & $\begin{array}{c}\text { Instru. } \\
\text { equation }\end{array}$ & Model 3 & $\begin{array}{c}\text { Instru. } \\
\text { equation }\end{array}$ & Model 4 & $\begin{array}{c}\text { Instru. } \\
\text { equation }\end{array}$ & Model 5 & $\begin{array}{c}\text { Instru. } \\
\text { equation }\end{array}$ & Model 6 & $\begin{array}{c}\text { Instru. } \\
\text { equation }\end{array}$ \\
\hline \multirow[t]{2}{*}{ Constant } & $-4.527 * * *$ & $2.306 * * *$ & $-5.292 * * *$ & $2.490 * * *$ & $-5.272 * * *$ & $2.314 * * *$ & $-6.197 * * *$ & $2.932 * * *$ & $-5.867 * * *$ & $2.988 * * *$ & $-6.337 * * *$ & $3.017 * * *$ \\
\hline & $(0.487)$ & $(0.357)$ & $(0.487)$ & $(0.408)$ & $(0.489)$ & $(0.422)$ & $(0.777)$ & $(0.556)$ & \begin{tabular}{|l}
$(0.950)$ \\
\end{tabular} & $(0.729)$ & $(0.879)$ & $(0.734)$ \\
\hline \multirow[t]{2}{*}{ COOP_INT } & $1.021 * * *$ & & $1.060 * * *$ & & $1.055^{* * * *}$ & & $1.070 * * *$ & & $1.069 * * *$ & & $1.099 * * *$ & \\
\hline & $(0.0929)$ & & \begin{tabular}{|l}
$(0.0941)$ \\
\end{tabular} & & $(0.0941)$ & & $(0.0953)$ & & \begin{tabular}{|l}
$(0.0953)$ \\
\end{tabular} & & $(0.0907)$ & \\
\hline \multirow[t]{2}{*}{ BT_LEVEL } & & $0.165 * * *$ & & $0.171 * * *$ & & $0.174 * * *$ & & $0.179 * * *$ & & $0.182 * * *$ & & $0.160 * * *$ \\
\hline & & $(0.0420)$ & & $(0.0406)$ & & $(0.0407)$ & & $(0.0385)$ & & $(0.0389)$ & & $(0.0408)$ \\
\hline \multirow[t]{2}{*}{ COOP_RES } & & $0.284 * * *$ & & $0.260 * * *$ & & $0.255^{* * * *}$ & & $0.252 * * *$ & & $0.248 * * *$ & & $0.276 * * *$ \\
\hline & & $(0.0733)$ & & $(0.0714)$ & & $(0.0702)$ & & $(0.0676)$ & & $(0.0686)$ & & $(0.0748)$ \\
\hline \multirow[t]{2}{*}{ REGULATION } & & $0.0964 * * *$ & & $0.0907 * * *$ & & $0.103^{* * *}$ & & $0.102 * * *$ & & $0.102 * * *$ & & $0.101 * * *$ \\
\hline & & $(0.0319)$ & & $(0.0328)$ & & \begin{tabular}{|l|}
$(0.0367)$ \\
\end{tabular} & & $(0.0360)$ & & $(0.0358)$ & & \begin{tabular}{|l|}
$(0.0358)$ \\
\end{tabular} \\
\hline \multirow[t]{2}{*}{ MANDA } & & $-0.199 *$ & & $-0.216^{* *}$ & & $-0.221 * *$ & & $-0.217 * *$ & & $-0.218 * *$ & & -0.173 \\
\hline & & $(0.107)$ & & $(0.103)$ & & \begin{tabular}{|l}
$(0.102)$ \\
\end{tabular} & & $(0.101)$ & & $(0.101)$ & & $(0.107)$ \\
\hline \multirow[t]{2}{*}{ Small } & & & $0.782 * * *$ & -0.139 & $0.794 * * *$ & -0.174 & $1.023 * * *$ & $-0.353^{*}$ & $1.017 * * *$ & $-0.355^{*}$ & $0.998 * * *$ & -0.353 \\
\hline & & & $(0.193)$ & $(0.167)$ & $(0.200)$ & $\begin{array}{l}(0.176) \\
\end{array}$ & $(0.273)$ & $(0.215)$ & $(0.272)$ & $(0.215)$ & $(0.272)$ & $(0.224)$ \\
\hline \multirow[t]{2}{*}{ Medium } & & & $0.537 * *$ & 0.109 & $0.544 * *$ & 0.0749 & $0.626^{* *}$ & 0.0125 & $0.602 * *$ & 0.0105 & $0.638^{* *}$ & -0.0119 \\
\hline & & & $(0.225)$ & $(0.183)$ & $(0.232)$ & $(0.188)$ & $(0.243)$ & $(0.194)$ & $(0.242)$ & $(0.195)$ & $(0.281)$ & $(0.201)$ \\
\hline \multirow[t]{2}{*}{ Private } & & & & & -0.0135 & 0.222 & 0.153 & 0.0964 & 0.147 & 0.0944 & 0.0281 & 0.0710 \\
\hline & & & & & $(0.167)$ & $(0.174)$ & $(0.216)$ & $(0.187)$ & $(0.220)$ & $(0.190)$ & $(0.220)$ & $\begin{array}{l}(0.197) \\
\end{array}$ \\
\hline \multirow[t]{2}{*}{ Foreign } & & & & & -0.00756 & $0.348^{* *}$ & 0.116 & 0.266 & 0.115 & 0.267 & 0.0471 & 0.234 \\
\hline & & & & & $(0.224)$ & $(0.171)$ & $(0.243)$ & $(0.175)$ & $(0.244)$ & $(0.175)$ & $(0.305)$ & $(0.175)$ \\
\hline \multirow[t]{2}{*}{ Age } & & & & & & & $0.226^{*}$ & $-0.166^{*}$ & $0.232^{*}$ & $-0.165^{*}$ & $0.275^{* * *}$ & $-0.163^{*}$ \\
\hline & & & & & & & $(0.132)$ & $(0.0965)$ & \begin{tabular}{|c|}
$(0.131)$ \\
\end{tabular} & $(0.0961)$ & $(0.134)$ & \begin{tabular}{|c|}
$(0.0933)$ \\
\end{tabular} \\
\hline \multirow[t]{2}{*}{ Relation } & & & & & & & & & -0.0876 & -0.0124 & -0.134 & -0.0186 \\
\hline & & & & & & & & & $(0.113)$ & $(0.0962)$ & $(0.128)$ & \begin{tabular}{|c|}
$(0.0977)$ \\
\end{tabular} \\
\hline \multirow[t]{2}{*}{ Central } & & & & & & & & & & & $0.669 * *$ & -0.130 \\
\hline & & & & & & & & & & & $(0.284)$ & \begin{tabular}{|l|}
$(0.209)$ \\
\end{tabular} \\
\hline \multirow[t]{2}{*}{ South } & & & & & & & & & & & $0.897 * *$ & 0.109 \\
\hline & & & & & & & & & & & $(0.353)$ & \begin{tabular}{|l|}
$(0.229)$ \\
\end{tabular} \\
\hline \multirow[t]{2}{*}{ athrho } & $-1.321 * * *$ & & $-1.507 * * *$ & & $-1.523 * * *$ & & $-1.519 * * *$ & & $-1.526 * * *$ & & $-1.481 * * *$ & \\
\hline & $(0.245)$ & & \begin{tabular}{|l|}
$(0.253)$ \\
\end{tabular} & & $(0.248)$ & & $(0.240)$ & & \begin{tabular}{|l|}
$(0.245)$ \\
\end{tabular} & & $(0.257)$ & \\
\hline $\begin{array}{l}\chi 2 \text { (Wald test of } \\
\text { exogeneity) }\end{array}$ & $29.15 * * *$ & & $35.53 * * *$ & & $37.59 * * *$ & & $40.12 * * *$ & & $38.77 * * *$ & & $33.26 * * *$ & \\
\hline Observations & 203 & 203 & 203 & 203 & 203 & 203 & 203 & 203 & 203 & 203 & 203 & 203 \\
\hline
\end{tabular}

Note. For limitation of space, rho index is not reported. Robust standard errors in parentheses. Statistically significant at $* * * \mathrm{p}<0.01, * * \mathrm{p}<0.05, * \mathrm{p}<0.1$. 


\subsection{Additional Discussion}

\subsubsection{The Effect Of Government Direction On Sectors}

In order to get better understanding about cooperation and the effect of government direction on each sector, the estimations are run with different type of partners. In this analysis, the foreign sector will be excluded because of the smallest sample size (only 23 respondents came from foreign enterprises) which causes no initial result in regression process. Therefore, only the results of state and private sector will be displayed in Table 3 which called by case 1 and case 2, respectively. Skipping the difference can be generated by sample size, the impact of organizational set and environmental one differs from both cases. The effect of trust on cooperative intention is higher for public sector. Similarity among these enterprises in this sector such as state ownership, management systems... can enhance level of trust between them and makes the outcome will be likely to satisfy both parties (Zucker, 1986).

Table 3. Estimation Result For Public Sector And Private Sector.

\begin{tabular}{|c|c|c|c|c|}
\hline VARIABLES & $\begin{array}{c}\begin{array}{c}\text { Public sector } \\
\text { model }\end{array} \\
\end{array}$ & $\begin{array}{c}\text { Instrument } \\
\text { equation }\end{array}$ & $\begin{array}{c}\begin{array}{c}\text { Private sector } \\
\text { model }\end{array} \\
\end{array}$ & $\begin{array}{c}\text { Instrument } \\
\text { equation }\end{array}$ \\
\hline \multirow[t]{2}{*}{ Constant } & $-8.856 * * *$ & 1.101 & $-6.304 * * *$ & $3.962 * * *$ \\
\hline & $(1.629)$ & $(1.178)$ & $(1.054)$ & $(0.962)$ \\
\hline \multirow[t]{2}{*}{ COOP_INT } & $2.247 * * *$ & & $0.972 * * *$ & \\
\hline & $(0.434)$ & & $(0.0927)$ & \\
\hline \multirow[t]{2}{*}{ BT_LEVEL } & & $0.244 * * *$ & & $0.170 * * *$ \\
\hline & & $(0.0712)$ & & $(0.0404)$ \\
\hline \multirow[t]{2}{*}{ COOP_RES } & & $0.299 * * *$ & & $0.259 * * *$ \\
\hline & & $(0.0927)$ & & $(0.0960)$ \\
\hline \multirow[t]{2}{*}{ REGULATION } & & $0.177 * * *$ & & 0.0301 \\
\hline & & $(0.0628)$ & & $(0.0443)$ \\
\hline \multirow[t]{2}{*}{ MANDA } & & -0.183 & & -0.160 \\
\hline & & $(0.251)$ & & $(0.137)$ \\
\hline \multirow[t]{2}{*}{ Small } & $1.489 * *$ & -0.251 & $1.054 * *$ & -0.642 \\
\hline & $(0.588)$ & $(0.346)$ & $(0.452)$ & $(0.468)$ \\
\hline \multirow[t]{2}{*}{ Medium } & $1.340 * *$ & -0.366 & $0.743^{*}$ & -0.259 \\
\hline & $(0.630)$ & $(0.254)$ & $(0.441)$ & $(0.449)$ \\
\hline \multirow[t]{2}{*}{ Age } & 0.144 & 0.00320 & $0.358^{*}$ & -0.211 \\
\hline & $(0.215)$ & $(0.146)$ & $(0.185)$ & $(0.141)$ \\
\hline \multirow[t]{2}{*}{ Relation } & $-0.805 * *$ & 0.0988 & -0.0592 & -0.0882 \\
\hline & $(0.374)$ & $(0.239)$ & $(0.144)$ & $(0.110)$ \\
\hline \multirow[t]{2}{*}{ Central } & 0.782 & -0.0622 & 0.679 & -0.160 \\
\hline & $(0.528)$ & $(0.239)$ & $(0.415)$ & $(0.359)$ \\
\hline \multirow[t]{2}{*}{ South } & 1.017 & 0.339 & $0.913^{*}$ & 0.0487 \\
\hline & $(0.646)$ & $(0.314)$ & $(0.494)$ & $(0.361)$ \\
\hline \multirow[t]{2}{*}{ athrho } & $-1.311 * *$ & & $-1.650 * * *$ & \\
\hline & $(0.525)$ & & $(0.330)$ & \\
\hline rho & -0.8645 & & -0.9289 & \\
\hline$\chi^{2}$ (Wald test of exogeneity) & $6.23 * *$ & & $24.99 * * *$ & \\
\hline Observations & 55 & 55 & 125 & 125 \\
\hline
\end{tabular}

Note: Robust standard errors in parentheses. Statistically significant at $* * * \mathrm{p}<0.01, * * \mathrm{p}<0.05, * \mathrm{p}<0.1$.

On the other hand, although regulation from government can foster inter-firm cooperation, this effect differs from sectors. From columns 2 and 4, we easily see the hallmark of this regulation is opaque in private sector. We cannot confirm the effect of regulation on inter-firm cooperation in private sector due to insignificant statistical evidence, while government direction plays important role in stimulating cooperation in state sector. This can be the 
effect of equalization process which applies for state owned enterprises ${ }^{6}$. In addition, resources have been dedicated to the strengthening of the state-owned sector, sometimes to the detriment of private enterprises (Giroud, 2007). In the meanwhile, restrictive regulations and unfriendly attitudes from officials seem to be kept towards private companies (Steer \& Sen, 2010). The high trust, along with fostering from government, has guaranteed the cooperative outcome and increase cooperative intention as the result.

\subsubsection{Vertical Versus Horizontal Cooperation}

Trust is broadly viewed as the means of cooperation. It has been viewed as most important element in explaining the difference from vertical and horizontal relationships (Rindfleisch, 2000 and Lancastre \& Lages, 2006). However, there are other factors that have contributed these differences. In investigating cooperation with supplier (vertical cooperation) versus competitor (horizontal cooperation) regardless of sector, the type of company (Private, State, Foreign) is excluded from estimation. The result which is shown in Table 4, indicates that inter-firm behavior, in the forms of benefit expectation and organizational trust, differs dramatically among horizontal versus vertical cooperation.

Table 4. Estimation result for IV probit model- Vertical versus Horizontal cooperation.

\begin{tabular}{|c|c|c|c|c|}
\hline VARIABLES & $\begin{array}{c}\text { (1) } \\
\text { Vertical model }\end{array}$ & $\begin{array}{c}\text { Instrument } \\
\text { equation }\end{array}$ & $\begin{array}{c}(2) \\
\text { Horizontal model }\end{array}$ & Instrument equation \\
\hline \multirow[t]{2}{*}{ Constant } & $-6.206 * * *$ & $3.308 * * *$ & $-7.199 * * *$ & $3.635 * * *$ \\
\hline & $(0.912)$ & $(0.727)$ & $(0.889)$ & $(0.970)$ \\
\hline \multirow[t]{2}{*}{ COOP_INT } & $1.084 * * *$ & & $1.351 * * *$ & \\
\hline & $(0.0954)$ & & $(0.140)$ & \\
\hline \multirow[t]{2}{*}{ BT_LEVEL } & & $0.167 * * *$ & & $0.0966 * *$ \\
\hline & & $(0.0457)$ & & $(0.0467)$ \\
\hline \multirow[t]{2}{*}{ COOP_RES } & & $0.286 * * *$ & & $0.230 * *$ \\
\hline & & $(0.0902)$ & & $(0.113)$ \\
\hline \multirow[t]{2}{*}{ REGULATION } & & $0.0978 * * *$ & & $0.0860 * *$ \\
\hline & & $(0.0350)$ & & $(0.0409)$ \\
\hline \multirow[t]{2}{*}{ MANDA } & & -0.162 & & $-0.397 * * *$ \\
\hline & & $(0.120)$ & & $(0.120)$ \\
\hline \multirow[t]{2}{*}{ Small } & $1.033 * * *$ & $-0.514 * *$ & $1.277 * * *$ & -0.414 \\
\hline & $(0.313)$ & $(0.245)$ & $(0.328)$ & $(0.295)$ \\
\hline \multirow[t]{2}{*}{ Medium } & $0.587 * *$ & -0.121 & $0.922 * *$ & -0.0619 \\
\hline & $(0.291)$ & $(0.202)$ & $(0.369)$ & $(0.232)$ \\
\hline \multirow[t]{2}{*}{ Age } & $0.261 * *$ & $-0.168^{*}$ & $0.396 * * *$ & $-0.180 *$ \\
\hline & $(0.126)$ & $(0.0942)$ & $(0.150)$ & $(0.106)$ \\
\hline \multirow[t]{2}{*}{ Relation } & -0.152 & -0.0556 & $-0.375 * *$ & 0.0797 \\
\hline & $(0.157)$ & $(0.0968)$ & $(0.161)$ & $(0.120)$ \\
\hline \multirow[t]{2}{*}{ Central } & $0.794 * *$ & -0.158 & $0.971 * *$ & -0.193 \\
\hline & $(0.311)$ & $(0.227)$ & $(0.381)$ & $(0.245)$ \\
\hline \multirow[t]{2}{*}{ South } & $0.920 * *$ & 0.116 & $0.774 *$ & 0.00127 \\
\hline & $(0.360)$ & $(0.241)$ & $(0.427)$ & $(0.248)$ \\
\hline \multirow[t]{2}{*}{ athrho } & $-1.490 * * *$ & & $-2.303 * * *$ & \\
\hline & $(0.289)$ & & $(0.504)$ & \\
\hline rho & -0.9032 & & -0.9802 & \\
\hline$\chi^{2}$ (Wald test of exogeneity) & $26.48 * * *$ & & $20.83 * * *$ & \\
\hline Observations & 181 & 181 & 132 & 132 \\
\hline
\end{tabular}

Note: Robust standard errors in parentheses. Statistically significant at $* * * \mathrm{p}<0.01, * * \mathrm{p}<0.05, * \mathrm{p}<0.1$

Firstly, cooperating with competitor is risky relationships. This can be due to the fear of opportunism when firm cooperates with competitors. The potential for opportunism is high as firms work in common project with

\footnotetext{
${ }^{6}$ According to decree No. 153/2004/NĐ-CP-Governmental decree on organizing and managing state enterprise.
} 
competitors and use this kind of relationships as a means to gain benefit at the expense of others. Therefore, companies participating in horizontal cooperation appear to be less trusting of their partners compared to companies in vertical cooperation relationships. This result is consistent with the finding of Rindfleisch (2000). Secondly, cooperation between competitor faces hard not just because of less trusting of their partner but mainly because of lower benefit from this type of relationship. The low level of expectation on relationship benefits makes them are not eager in making relationships with its competitor. This can be explained by the fact that goals between competitors who work together are more likely to conflict. In addition, they can take advantage to undermine the benefit of other (Park \& Russo, 1996).

The effect of environment on inter-firm relationship also differs from both cases. Although the impact of government direction on inter-firm relationships almost is same in both, the negative effect of social norm by compulsory cooperation on inter-firm relationship is more clearly in horizontal model. Through working in common business, chance is likely opened for firm to watch over its competitors. Taking opportunities, setting different targets and undermining opponent's interest from competitors are recorded. All of these have resulted in high coefficient of MANDA variable (effect of social influence represented by mandatory relationship) and contributed to reduce the chance for cooperation with competitor. On the whole, there are other factors contribute the difficulties for cooperation between competitor.

\section{CONCLUSION}

The trend of inter-firm cooperation has increased in recent year because firm cannot operate alone in the present global economy. In such objective of enhancing inter-firm cooperation, authors have tried to investigate factors as well as mechanism for operation (Morgan \& Hunt, 1994; Okamuro, 2007). Among the researches, authors do not include the behavior intention in their model. Even with Jeffries \& Becker (2008), they tested the simplified model but in personal's view, not in firm's level. The need to build up integrate framework which integrates influencing factors and behavior intention based on theory of reasoned action (Fishbein \& Ajzen, 1975) in order to explain firm behavior becomes the main objective of the paper.

The empirical results from Vietnamese enterprises data above strongly support the integrated model for inter-firm relationships. It indicates that behavior intention is the sole precedent and mediator for any inter-firm behavior. This result brings the other view on organizational behavior theory. Firstly, the behavioral intention is the most important component to explain any behavior not only for personal view but also for company level. Without intention or low level of it, trust and other factors cannot fully lead to behavior especially inter-firm cooperation behavior. This finding differs from the commitment-trust theory of Morgan \& Hunt (1994). Secondly, in analyzing organizational behavior, we have to consider both organizational factors and environmental set. Among them, expectation of benefit which generates from forthcoming cooperation project influences significantly cooperation decision through intention. This can explain why companies can reach inter-firm relationships even in the first time if common interests can be found. Thirdly, the results also support the positive effect of government direction on inter-firm relationships. Through management tools such as promulgating an act or publishing policies, government can foster this kind of relationships. One interesting finding comes from the impact of working in the same project. This mandatory relationship only act against inter-firm cooperation.

Beyond this confirmation, we also found the truth effect of government direction by running estimation with different sectors. Although direction from government can enhance inter-firm cooperation in general, this seems to effect only for state enterprises. Similarity in characteristics and the impact of regulation contribute to intensify trust as well as intention to cooperate among partner. The government, in caring of it enterprises, can design distorted regulations that favor the firms in which its share is significant? ${ }^{7}$ Therefore, according to Vietnamese context, the state owned enterprises themselves are more likely to cooperate compared with private sector. This also requires much attention from officials in simulating cooperation among economic agents.

\footnotetext{
${ }^{7}$ Anh, T.T.Vu (2006). Competition and Privatization in Vietnam: Substitutes or Complements? The 2nd Vietnam Development Forum Tokyo Conference on the Development of Vietnam, 15 July 2006 at GRIPS, Tokyo.
} 
We may useful distinguish between two different sets of factor which contribute the difference in cooperation between horizontal and vertical analyses. In the form of organizational set, opportunism and conflict goals have reduced relationship benefits and trust among enterprises competing against one another. The empirical result indicates the remarkable impact of compulsory relationship for working in common business. Company does not like its competitor in nature. Hence, mandatory relations just dig deep into the foundation of doubt and contradiction. This creates the barrier for cooperation between them.

\section{ACKNOWLEDGEMENTS}

The author expresses his deeply thank to Prof. Fumitoshi Mizutani at Kobe University for comments and valuable suggestions. The author is grateful to Prof. Kennichi Shoji at Kobe University for supporting fund for the research.

\section{AUTHOR INFORMATION}

Nguyen Phuc Nguyen is Ph.D candidate in Management at Graduate school of Business Administration - Kobe University, Japan. Before entering Ph.D program, he is a lecturer at the Faculty of Business Administration at Da Nang University, Vietnam. He holds MSc degree from Asian Institute of Technology (AIT)- Thailand.

\section{REFERENCES}

1. Adobor, Henry (2006). Inter-firm collaboration: Configurations and dynamics. Competitiveness Review. Vol. 16, pp. 122-134.

2. Ajzen, I. \& Madden, T. J. (1986). Prediction of goal-directed behavior: Attitudes, intentions, and perceived behavioral control. Journal of Experimental Social Psychology, Vol. 22, pp. 453-474.

3. Amemiya Takeshi (1978). The estimation of a simultaneous equation generalized probit model. Econometrica, Vol. 46, pp. 1193-1205.

4. Andaleeb, S. S. (1995). Dependence relations and the moderating role of trust: implications for behavioral intentions in marketing channels. International Journal of Research in Marketing, Vol. 12, pp. 157-172.

5. Anderson, J. C. \& Narus, J. A. (1990). Model of distributor firm and manufacturer firm working partnerships. The Journal of Marketing, Vol. 54, pp. 42-58.

6. Arku, Godwin (2002). Collaboration in industry: Empirical findings among small electronics manufacturing firms in the Greater Toronto Area. GeoJournal, Vol. 57, pp. 301-312

7. Axelrod, R. (1984). The Evolution of Cooperation. New York: Basic Books.

8. Becker, W. \& Dietz, J. (2004). R\&D cooperation and innovation activities of firms - Evidence for the German manufacturing industry. Research Policy, Vol. 33, pp. 209-223

9. Belderbos, R., Carree, M. \& Lokshin, B. (2004). Cooperative R\&D and firm performance. Research Policy, Vol. 33, pp. 1477-1492

10. Bengtsson, M. \& Kock, S. (2000). Co-operation in business networks- To cooperate and compete simultaneously. Industrial Marketing Management, Vol. 29, pp. 411-426.

11. Blomqvist, K. (1997). The many faces of trust. Scandinavian Journal of Management, Vol. 13, pp. 271286.

12. Cameron, A. C. \& Trivedi, P. K. (2009). Microeconometrics using STATA. A Stata Press Publication.

13. Cannon, J. P. \& Perreault, W. D. Jr. (1999). Buyer-Seller Relationships in Business Markets. Journal of Marketing Research, Vol. 36, pp. 439-460.

14. Cho, D. H \& Yu, P. I. (2000). Influential factors in the choice of technology acquisition mode: an empirical analysis of small and medium size firms in the Korean telecommunication industry. Technovation, Vol. 20, pp. 691-704.

15. Davis, F. D. (1986). A technology acceptance model for empirically testing new end-user information systems: Theory and results. (Doctoral dissertation, Sloan School of Management, Massachusetts Institute of Technology).

16. Dowling, M. \& Helm, R. (2006). Product development success through cooperation: A study of entrepreneurial firms. Technovation, Vol. 26, pp. 483-488. 
17. Dyer, J. H. \& Chu,W. (2003). The role of trustworthiness in reducing transaction costs and improving firm performance: Empirical evidence from the United State, Japan and Korea. Organization Science, Vol. 14, pp. 57-68.

18. Edelenbos, J. and Klijn, E-H. (2007). Trust in complex decision-making networks: A theoretical and empirical exploration. Administration \& Society, Vol. 39, pp. 25-50.

19. Evan, W. M. (1965). Toward a theory of inter-organizational relations. Management Science, Vol. 11, pp. B217-B230.

20. Fang, E., Palmatier, R. W., Scheer, L. K \& Li, N. (2008). Trust at different organizational levels. Journal of Marketing, Vol. 72, pp. 80-98.

21. Felzensztein, C. \& Gimmon, E. (2007). The influence of culture and size upon inter-firm marketing cooperation. A case study of salmon farming industry. Marketing Intelligence \& Planning, Vol. 25, pp. 377-393.

22. Fishbein, M. \& Ajzen, I. (1975). Belief, Attitude, Intention and Behavior: An Introduction to Theory and Research. Addision-Wesley Addison-Wesley series in social psychology.

23. Friman, M., Gärling, T., Millett, B., Mattsson, J. \& Johnston, R. (2002). An analysis of international business to business relationships based on the commitment-trust theory. Industrial Marketing Management, Vol. 32, pp. 403-409.

24. Fritsch. M. \& Lukas. J. (2001). Who cooperates on R\&D? Research Policy, Vol. 30, pp. $297-312$.

25. Fritsch Michael (2003). Does R\&D cooperation behavior differ between regions? Industry and Innovation, Vol. 10, pp. 25-39.

26. Giroud Axèle (2007) MNEs vertical linkages: The experience of Vietnam after Malaysia. International Business Review, Vol. 16, p. 159-176.

27. Hagen, J. M. \& Choe, S. (1998). Trust in Japanese interfirm relations: Institutional sanctions matter. Academy of Management Review, Vol. 23, pp. 589-600.

28. Ha kansson, H. \& Snehota, I. (1995). Developing Relationships in Business Networks. Routledge, London.

29. Heikki, K., Heikki, L., Matti, L. \& Chanaka, J. (2008). Exploring gender influence on customer's intention to engage permission-based mobile marketing. Electronic Markets, Vol. 18, pp. 242-259.

30. Huybers. T. \& Bennett. J. (2003). Inter-firm cooperation at nature-based tourism destinations. Journal of Socio-Economics, Vol. 32, pp. 571-587.

31. Hwang, P. \& Burgers, W. P. (1997). Properities of trust: An analytical view. Organizational Behavior and Human Decision Processes, Vol. 69, pp. 67-73.

32. Inzelt Annamária (2004). The evolution of university-industry-government relationships during transition. Research Policy, Vol. 33, pp. 975-995.

33. Jeffries, F. J., \& Becker, T. E. (2008). Trust, norms, and cooperation: Development and test of a simplified model. Journal of Behavioral and Applied Management, Vol. 9, pp. 316-336.

34. Kipping Mattihias (1996). Inter-firm relations and industrial policy: The French and German steel producers and users in the twentieth century. Business History, Vol. 38, pp. 1-25.

35. Kutner, M. H., Nachtsheim, C. J., Neter, J. \& Li, W. (2004). Applied Linear Statistical Models, $5^{\text {th }}$ edition. McGraw-Hill/Irwin

36. Lancastre, A. \& Lages, L. F. (2006). The relationship between buyer and a B2B e-marketplace: Cooperation determinants in an electronic market context. Industrial Marketing Management, Vol. 35, pp. 774-789.

37. Malecki, E. J. \& Veldhoen, M. E. (1993). Network activities, information and competitiveness in small firms. Geografiska Annaler. Series B, Human Geography, Vol. 75, pp. 131-147

38. Malhotra, Y. \& Galletta, D. F. (1999). Extending the technology acceptance model to account for social influence: Theoretical bases and empirical validation. Proceedings of the Thirty-Second Annual Hawaii International Conference on System Sciences.

39. Mayer, R. C., Davis, J. H. \& Schoorman, F. D (1995). An integrative model of organizational trust. Academy of Management Review, Vol. 20, pp. 709-734.

40. McMillan, J. \& Woodruff, C. (1999). Inter-firm relationships and informal credit in Vietnam. The Quarterly Journal of Economics, Vol. 114, pp. 1285-1320.

41. McKnight, D. H., Cummings, L. L. \& Chervany, N. L. (1998). Initial trust formation in new organizational relationships. Academy of Management Review, Vol. 23, pp. 473-490. 
42. Morgan, R. M. and Hunt, S. D. (1994). The commitment-trust theory of relationship marketing. Journal of Marketing, Vol. 58, pp. 20-38.

43. Morris, M. \& Carter, C. R. (2005). Relationship marketing and supplier logistics performance: An extension of the key mediating variables model. The Journal of Supply Chain Management, Vol. 41, pp. $32-43$.

44. Nakamura, M., Vertinsky, I. \& Zietsma, C. (1997). Does culture matter in inter-firm cooperation? Research consortia in Japan and the USA. Managerial and Decision Economics, Vol. 18, pp. 153-175.

45. Okamuro Hiroyuki (2007). Determinants of successful R\&D cooperation in Japanese small business: The impact of organizational and contractual characteristics. Research Policy, Vol. 36, pp. 1529-1544.

46. Park, S. H \& Russo, M. V.,(1996). When competition eclipses cooperation: An event history analysis of joint venture failure. Management Science, Vol. 42, pp. 875-890.

47. Payan, J. M. (2007). A review and delineation of cooperation and coordination in marketing channels. European Business Review, Vol. 19, pp. 216-233.

48. Rindfleisch Aric (2000). Organization trust and inter-firm cooperation: An examination of horizontal versus vertical alliances. Marketing Letters, Vol. 11, pp. 81-95.

49. Ring, P. S \& Van de Ven, A. H. (1992). Structuring cooperative relationships between organizations. Strategic Management Journal, Vol. 13, pp. 483-498.

50. Rivers, D. \& Vuong, Q. H. (1988). Limited information estimators and exogeneity tests for simultaneous probit models. Journal of Econometrics, Vol. 39, pp. 347-366.

51. Rosenfeld, S. A. (1996). Does cooperation enhance competitiveness? Assessing the impacts of inter-firm collaboration. Research Policy, Vol. 25, pp. 247-263.

52. Rousseau, D. M., Sitkin, S. B., Burt, R. S. \& Camerer, C. (1998). Not so different after all: A crossdiscipline view of trust. The Academy of Management Review, Vol. 23, pp. 393-404.

53. Ryan, M. J. \& Bonfield, E.H. (1980). Fishbein's intention model: A test of external and pragmatic validity. Journal of Marketing, Vol. 44, pp. 82-95.

54. Saito, Y. U., Watanabe, T. \& Iwamura, M. (2007). Do large firms have more inter-firm relationships?. Physica A, Vol. 383, pp. 158-163.

55. Schermerhorn, J. R., Jr. (1975). Determinants of interorganizational cooperation. The Academy of Management Journal, Vol. 18, pp. 846-856.

56. Silipo, D. B. (2005). The evolution of cooperation in patent races: Theory and experimental evidence. Journal of Economics, Vol. 85, pp. 1-38.

57. Smith, K. G., Carroll, S. J. \& Ashford, S. J (1995). Intra- and interorganizational cooperation: Toward a research agenda. The Academy of Management Journal, Vol. 38, pp. 7-23

58. Steer, L. \& Sen, K. (2010). Formal and informal institutions in a transition economy: The case of Vietnam. World Development, Vol. 38, pp. 1603-1615.

59. Stutzman, T.M. \& Green, S.B. (1982). Factors affecting energy consumption: Two field tests of the Fishbein-Ajzen model. Journal of Social Psychology, Vol. 117, pp. 183-201.

60. Thompson, K. E. \& Panayiotopoulos, P. (1999). Predicting behavioural intention in a small business context. Journal of Marketing Practice: Applied Marketing Science, Vol. 5, pp. 89-96.

61. Tran. T. B, Grafton, R. Q. \& Kompas. Tom (2009). Institutions matter: The case of Vietnam. The Journal of Socio-Economics. Vol. 38, pp. 1-12.

62. Warner, John A III (1995). Studies of individualism-collectivism: Effect on cooperation in groups. The Academy of Management Journal, Vol. 38, pp. 152-172. 
Appendix A. Characteristics Of Surveyed Firm (Display In Percent Number Of Surveyed Firms)

\begin{tabular}{|c|c|c|c|c|}
\hline 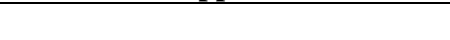 & Type Of Firm & Public & Private & Foreign \\
\hline \multirow[t]{3}{*}{ Field of operation } & Manufacturing & 2.96 & 4.43 & 2.46 \\
\hline & Services & 19.7 & 45.81 & 6.4 \\
\hline & $\operatorname{Mix}(\mathrm{M} \& S)$ & 4.43 & 11.33 & 2.46 \\
\hline \multirow[t]{3}{*}{ Size of firm } & Small & 12.81 & 46.8 & 3.94 \\
\hline & Medium & 5.42 & 11.33 & 2.46 \\
\hline & Large & 8.87 & 3.45 & 4.93 \\
\hline \multirow[t]{4}{*}{ Age of firm } & $<5$ years & 1.48 & 18.72 & 1.97 \\
\hline & $5-9$ years & 7.88 & 20.69 & 2.46 \\
\hline & $10-15$ years & 1.97 & 16.75 & 2.46 \\
\hline & $>15$ years & 15.76 & 5.42 & 4.43 \\
\hline \multirow[t]{3}{*}{ Location of firm } & North & 7.88 & 11.33 & 3.45 \\
\hline & Central & 14.78 & 31.53 & 4.43 \\
\hline & South & 4.43 & 18.72 & 3.45 \\
\hline \multirow[t]{4}{*}{ Number of inter-firm relationships } & $1-5$ companies & 0.49 & 1.48 & 0 \\
\hline & 6-10 companies & 0.49 & 6.4 & 0.49 \\
\hline & 11-15 companies & 2.96 & 6.9 & 0.49 \\
\hline & $>15$ companies & 23.15 & 46.8 & 10.34 \\
\hline
\end{tabular}


Appendix B. Definitions Of Variables And Descriptive Statistics

\begin{tabular}{|c|c|c|c|}
\hline Variable & Description & Mean & $\begin{array}{l}\text { Standard } \\
\text { Deviation }\end{array}$ \\
\hline COOP_DECI & $\begin{array}{l}\text { Dummy variable for cooperation which } 1 \text { represent inter-firm cooperation and zero } \\
\text { for otherwise. }\end{array}$ & 0.7389 & 0.4403 \\
\hline COOP_INT & $\begin{array}{l}\text { This measures the company's intent to cooperate with other firms. 1: lowest level } \\
\text { and and } 7 \text { is highest level using } 7 \text {-point Likert scale. }\end{array}$ & 4.9113 & 1.2195 \\
\hline BT_LEVEL & $\begin{array}{l}\text { Trust level at the time making cooperative decision - using 7-point Likert scale } \\
\text { with anchor 1: not trust at all and } 7 \text { is totally trust }\end{array}$ & 5.4729 & 1.5231 \\
\hline COOP_RES & $\begin{array}{l}\text { This measures the level of expectation on relationships' result if cooperative } \\
\text { decision is made using 7-point Likert scale with anchor 1: lowest level and and } 7 \text { is } \\
\text { highest level. }\end{array}$ & 5.2266 & 1.3526 \\
\hline REGULATION & $\begin{array}{l}\text { This order variable measure the influence of regulation from government on inter- } \\
\text { firm cooperation using } 7 \text {-point Likert scale with } 1 \text { is strongly unaffected and } 7 \text { is } \\
\text { strongly affected. }\end{array}$ & 3.1872 & 1.7362 \\
\hline MANDA & $\begin{array}{l}\text { Dummy variable for inter-firm cooperation due to social influence by compulsory } \\
\text { relationship for working in common project. }\end{array}$ & 0.4384 & 0.4974 \\
\hline Small & Dummy variable for small firm (less than 200 employees) & 0.6355 & 0.4825 \\
\hline Medium & Dummy variable for medium firms (200-300 employees) & 0.1921 & 0.3949 \\
\hline Large & $\begin{array}{l}\text { Dummy variable for large firms (more than } 300 \text { employees)-excluded from model } \\
\text { as a reference group. }\end{array}$ & 0.1724 & 0.3787 \\
\hline Age & $\begin{array}{l}\text { Age of company. This is order variable with } 1:<5 \text { years; } 2: 5-9 \text { years; } 3: 10-15 \\
\text { years and 4:>15 years }\end{array}$ & 2.5025 & 1.1007 \\
\hline North & $\begin{array}{l}\text { Dummy variable for firms located in north of Vietnam-excluded from model as a } \\
\text { base. }\end{array}$ & 0.2020 & 0.4025 \\
\hline Central & Dummy variable for firms located in the central. & 0.5320 & 0.5012 \\
\hline South & Dummy variable for firms located in the south. & 0.2660 & 0.4430 \\
\hline Private & Dummy variable for private enterprises & 0.6158 & 0.4876 \\
\hline Foreign & Dummy variable for foreign related enterprises & 0.1133 & 0.3177 \\
\hline State & $\begin{array}{l}\text { Dummy variable for state owned enterprises- excluded from model as a control } \\
\text { group. }\end{array}$ & 0.2709 & 0.4455 \\
\hline Relation & $\begin{array}{l}\text { Order variable measure experiences of firm in term of the number of relations with } \\
\text { other companies in which } 1: 1-5 \text { relations; } 2: 6-10 \text { relations; } 3: 11-15 \text { relations and } \\
\text { 4: }>15 \text { relations }\end{array}$ & 3.6897 & 0.6946 \\
\hline Supplier & Dummy variable for cooperation with supplier & 0.8916 & 0.3116 \\
\hline Competitor & Dummy variable for cooperation with competitor & 0.6502 & 0.4781 \\
\hline
\end{tabular}


Appendix C. The Estimation Method

The analysis starts with estimating an empirical model of inter-firm cooperation in which intent to cooperate is assumed to be an endogenous regressor. The model is the form of structural equation as:

$$
y_{i}^{*}=\alpha * Y_{i}+\beta * X_{i}+e_{i}
$$

where $y_{i}^{*}$ represents the latent variable denoting the unobserved propensity of firm A to be committed to cooperate with firm B. $Y_{i}$ is the intention for inter-firm cooperation, $\alpha$ is its coefficient; $X_{i}$ denote the vector of firm and regional characteristics influencing the cooperative decision, $\beta$ is the vector of coefficients and $e_{i}$ is the errors.

Let $y_{i}$ denotes the decision of the enterprise $\mathrm{i}$ whether or not to make cooperation decision. Although $y_{i}^{*}$ is unobserved but its sign can be seen, such that

$$
y_{1}= \begin{cases}1 & \text { if } \mathrm{y}_{\mathrm{i}}^{*}>0 \\ \hline 0 & \text { otherwise }\end{cases}
$$

The coefficients in equation (1) can be estimated with the probit procedure. However, this result is not good as expect. Firstly, probit regression cannot explain correctly and fully the effect of cooperative intention on cooperative decision because it treats all variables equally. Cooperative intention is not the mediator for other antecedents as logic of theory of reasoned action (Fishbein \& Ajzen, 1975). Secondly, probit model will create bias in estimating coefficients. The requirement for consistent estimates is that the explanatory variables and other variables are not correlated. However, unobserved enterprise and cultural characteristics, which affect both the intention to cooperation and the cooperation decision as well, can produce a correlation between $Y_{i}$ and $e_{i}$. This will create bias in estimating $\alpha$ and other coefficients latterly. Therefore, consisting with theoretical model and overcoming these problems, we apply instrumental variable probit model for estimation (see Amemiya, 1978; Rivers $\&$ Vuong, 1988). The instrumental equation is as:

$$
Y_{i}=\eta * Z_{i}+\gamma * X_{i}+v_{i}
$$

In which $\eta$ and $\gamma$ are the vectors of coefficients in instrument equation. $Z_{i}$ is the vector of identifiers (this vector represents the determinants of cooperative intention) and $v_{i}$ is the error term.

The parameters of the probit (1) and the instrument equation (3) can be jointly estimated by maximum likelihood. We write the joint density $f\left(y_{i}^{*}, Y_{i} \mid X_{i}, Z_{i}\right)$ as $f\left(y_{i}^{*} \mid Y_{i}, X_{i}, Z_{i}\right) f\left(Y_{i} \mid X_{i}, Z_{i}\right)$ and thus, the log likelihood for observation i is as follows:

$$
\ln L_{i}=y_{i}^{*} \ln \Phi\left(m_{i}\right)+\left(1-y_{j}^{*}\right)\left[1-\Phi\left(m_{i}\right)\right]+\ln \Psi\left(\frac{Y_{i}-\gamma X_{i}-\eta Z_{i}}{\delta}\right)-\ln (\delta)
$$

where

$$
m_{i}=\frac{\alpha Y_{i}+\beta X_{i}+q\left(Y_{i}-\gamma X_{i}-\eta Z_{i}\right) / \delta}{\sqrt{\left(1-q^{2}\right)}}
$$

$\Phi($.$) and \Psi($.$) are the standard normal distribution and density functions, respectively, \delta$ is the standard deviation of $v_{i}$ and $q$ the correlation coefficient between $e_{i}$ and $v_{i}$. 


\begin{tabular}{|c|c|c|c|c|c|c|c|c|c|c|c|c|c|c|c|c|}
\hline \multicolumn{17}{|c|}{ Appendix D. Pairwise Correlations Among Constructs } \\
\hline Constructs & 1 & 2 & 3 & 4 & 5 & 6 & 7 & 8 & 9 & 10 & 11 & 12 & 13 & 14 & Tolerance & VIF \\
\hline COOP_DECI & 1.000 & & & & & & & & & & & & & & 0.3645 & 2.74 \\
\hline COOP_INT & $0.528 * *$ & 1.000 & & & & & & & & & & & & & 0.5939 & 1.68 \\
\hline BT_LEVEL & $0.576 * *$ & $0.311 * *$ & 1.000 & & & & & & & & & & & & 0.5820 & 1.72 \\
\hline COOP_RES & $0.599 * *$ & $0.516 * *$ & $0.534^{*}$ & 1.000 & & & & & & & & & & & 0.5075 & 1.97 \\
\hline REGULATION & $0.317 * *$ & $0.286^{* *}$ & $0.193 * *$ & $0.307 * *$ & 1.000 & & & & & & & & & & 0.7386 & 1.35 \\
\hline MANDA & -0.085 & $-0.140 *$ & 0.006 & -0.090 & 0.031 & 1.000 & & & & & & & & & 0.8926 & 1.12 \\
\hline Small & 0.016 & $-0.181 *$ & -0.074 & $-0.176^{*}$ & $-0.237 * *$ & 0.071 & 1.000 & & & & & & & & 0.3623 & 2.76 \\
\hline Medium & $0.148^{*}$ & $0.149^{*}$ & 0.079 & 0.131 & $0.178^{*}$ & -0.003 & $-0.644 * *$ & 1.000 & & & & & & & 0.4919 & 2.03 \\
\hline Private & -0.002 & -0.099 & -0.098 & -0.132 & $-0.320 * *$ & $0.179 *$ & $0.336 * *$ & -0.031 & 1.000 & & & & & & 0.5446 & 1.84 \\
\hline Foreign & 0.071 & 0.128 & 0.042 & 0.090 & 0.114 & -0.128 & $-0.214 * *$ & 0.023 & $-0.457 * *$ & 1.000 & & & & & 0.7427 & 1.35 \\
\hline Age & 0.027 & -0.015 & 0.082 & 0.119 & $0.179 *$ & -0.007 & $-0.464 * *$ & $0.175^{*}$ & $-0.419 * *$ & 0.105 & 1.000 & & & & 0.6422 & 1.56 \\
\hline Relation & -0.088 & -0.027 & 0.013 & -0.057 & -0.021 & -0.063 & 0.001 & -0.088 & $-0.145^{*}$ & 0.093 & 0.069 & 1.000 & & & 0.9411 & 1.06 \\
\hline Central & 0.065 & -0.072 & 0.119 & 0.034 & -0.041 & 0.136 & 0.073 & -0.045 & 0.022 & -0.083 & -0.007 & -0.057 & 1.000 & & 0.5282 & 1.89 \\
\hline South & $0.282 * *$ & $0.154^{*}$ & 0.106 & 0.098 & 0.057 & $-0.150 *$ & 0.062 & 0.074 & 0.103 & 0.031 & -0.113 & 0.061 & $-0.611 * *$ & 1.000 & 0.4825 & 2.07 \\
\hline
\end{tabular}

Note: Correlation is significant at $* * \mathrm{p}<0.01,{ }^{*} \mathrm{p}<0.05$ (2-tailed) 
International Journal of Management \& Information Systems - Third Quarter $2011 \quad$ Volume 15, Number 3 NOTES 